\title{
Narratiivin ontologia ja differentiaalinen narratologia
}

\section{Ridvan Askin, Narrative and Becoming. Edinburgh, Edinburgh University Press 2016, 213 S.}

"Narratologia ei ole koskaan ollut tarpeeksi abstraktia", väittää Ridvan Askin (s. 16), Baselin yliopistossa toimiva kirjallisuudentutkija. Askinin mukaan narratologia ei ole kyennyt määrittelemään narratiivia riittävän abstraktilla tasolla muotoillessaan empiirisiä vastauksia kysymykseen, joka on perustaltaan metafyysinen. Narrative and Becoming -teoksessaan Askin itse paneutuu narratiiviin nimenomaisesti ontologisena kategoriana ja siten osana metafysiikkaa.

Jo ensi virkkeistä lähtien Askinin teos ilmoittaa asettuvansa vastoin narratologian perusasetelmia, jotka tutkimus nimeää niin itsestään selvinä otetuiksi, että niitä harvemmin edes kirjoitetaan esiin. Askinin mukaan narratiivia käsittelevät teoriat rakentuvat ensinnäkin ihmiskeskeisyydelle, toiseksi epistemologialle ja kolmanneksi kokemuksellisuudelle. Narratiivi on redusoitu kognitiiviseksi prosessiksi, ihmisyyden narsistiseksi leikkikentäksi ja kokemuksen representaatioksi, Askin tykittää. Näiden taustaksi Askin nimeää kantilaisen filosofian ja siitä kumpuavan korrelationalismin. Askin nojaa Quentin Meillassoux'n näkemyksiin, joiden mukaan korrelationalismissa ajattelun ja olemisen välillä on korrelaatio eikä ihminen voi tavoittaa maailmallisia olioita sinänsä - kuten vaikkapa narratiiveja. Askin puolestaan esittää, että narratiivin käsite on riippuvainen ihmismielestä, mutta itse narratiivi ei välttämättä ole. Jotta narratiivista voi väittää epistemologisesti jotain, pitää pohtia narratiivin ontologiaa, narratiivia itseään. Sen pohtimisessa erilaiset narratologiat eivät Askinin mukaan ole menneet tarpeeksi pitkälle.

Askin kutsuu kehittelemäänsä lähestymistapaa "differentiaaliseksi narratologiaksi", tosin tutkimuksessa vilahtaa kerran narr-on-tologia -termi (s. 176), joka heitonomaisuudessaankin kiteyttää Askinin tutkimuksen tavoitteet. Teos koostuu laajasta johdannosta, jossa Askin tekee eroa erilaisiin narratologioihin ja erityisesti niiden representationalistiseen tapaan tarkastella narratiiveja. Johdannossa Askin esittää myös differentiaalisen narratologian lähtökohtia. Johdannon jälkeen seuraa neljä lukua, joissa kussakin Askin lukee tarkasti kaunokirjallisia narratiiveja kehitellen näkemyksiään eteenpäin. Tutkimus päättyy yhteenvetoon. Askinin teos kytkeytyy niin posthumanistiseen ajatteluun kuin viimeaikaiseen filosofiseen "spekulatiiviseen käänteeseen". Ennen kaikkea Narrative and Becoming -teosta lävistää Gilles Deleuzen (1925-1995) ajattelu. 
Pyrkiessään sanomaan narratiiveista ja niiden ontologiasta jotakin "tarpeeksi abstraktia" Askin nojaa erityisesti Deleuzen Différence et répétition -teokseen (1968) ja siinä kehiteltyyn transsendentaaliseen empirismiin. Deleuzelle transsendentaalinen Ideoitten alue tuottaa empiirisen kokemuksen kentän, ja nämä molemmat alueet yhdessä ovat todellisuuden aluetta, "puhdasta immanenssia”. Deleuzen käsitteistössä puhutaan 'virtuaalisesta' eikä transsendentaalisesta ja 'aktuaalisesta' eikä empiirisestä. Virtuaalisen ja aktuaalisen välinen suhde ei ole representationaalinen vaan ilmaiseva. Virtuaalinen ja aktuaalinen muuntuvat toisikseen vastavuoroisessa tulemisen tapahtumassa, jota Deleuze kuvaa 'intensiivisen' käsitteellä. Askinin narratologiassa näitä käsitteitä käytetään hyväksi määriteltäessä narratiivia. Virtuaalinen narratiivin idea saa ilmaisunsa aktuaalisissa narratiiveissa eli konkreettisissa kertomuksissa. Representationalistinen ajattelu nojaa analogiaan ja samankaltaisuuteen sekä niin sanottuun negatiiviisen eroon eli ajatukseen, jossa ilmiöitten välisten erojen ajatellaan syntyvän niiden välisestä suhteesta. Deleuzen ajattelu sen sijaan nojaa näkemykseen "puhtaasta erosta" eli eroavaisuudesta sinänsä. Askinin nimitys "differentiaalinen narratologia" onkin yhtäältä paradoksinen: se etsii narratiivin ontologiaa, olemisen tapaa, mutta samalla kaihtaa yleiskäsitteitä, jotka kattaisivat kaikkia narratiiveja. Yleiskäsite ei ole mahdollinen, sillä aktuaaliset narratiivit ilmaisevat aina eroavaisuutta.

Aktuaalisten narratiivien luennassa Askin viljelee runsaasti muita Deleuzen yksin ja yhdessä Félix Guattarin (1930-1992) kanssa luomia käsitteitä, kuten vaikkapa 'affekti', 'intensiiviset voimat', 'tuleminen-havaitsemattomaksi' ja 'aistimus'. Näitä käsitteitä käytetään yhdessä narratologisten perustermien kanssa. Sinällään on mielenkiintoista, että Askin käyttää useita Deleuzen yksin tai yhdessä Guattarin kanssa kirjoittamia teoksia hyväkseen, mutta sivuuttaa filosofien yksinomaan kirjallisuuteen keskittyvän tuotannon. Niinpä esimerkiksi Deleuzen Marcel Proust et les signes (1964), Présentation de Sacher-Masoch (1967) ja Critique et clinique (1993) tai Deleuzen ja Guattarin Kafka. Pour une littérature mineure (1975) eivät ole Askinin tutkimuksen lähteinä. Esimerkiksi Critique et clinique -teoksen "kriittiset ja kliiniset esseet" sisältävät Deleuzen näkemyksiä, jotka hahmottavat juuri sellaista lukemisen tapaa - jopa metodologiaa - jota Askin teoksessaan tavoittelee. Myös Deleuzen ja Guattarin Kafkaa käsittelevässä teoksessa määritelty "vähäkirjallisuus" ('une littérature mineure') ja sen keskeiset olemisen tavat olisivat olleet hyödynnettävissä myös Askinin kaunokirjallisuusanalyyseissä. Kenties näiden teosten sekä myös lukuisten kansainvälisten deleuzeläistä kirjallisuudentutkimusta edustavien tutkimusten puuttuminen Askinin teoksesta liittyy siihen, että Askinin painopiste on Deleuzeen nojaavan narratologian hahmottamisessa; narratologia ei ole ollut Deleuzen itsensä, saati deleuzeläisen kirjallisuudentutkimuksen kiinnostuksen kohteena.

Lukemisen peruskysymyksiksi Askin ilmoittaa suoraan Deleuzeltä ja Guattarilta lainatut muotoilut. Sen sijaan, että kysyisi, "mitä tämä (narratiivi) merkitsee?", Askin kysyy, "miten se toimii?” ja "mitä se tekee?". Näihin kysymyksiin 
vastatessaan Askin pyrkii pakenemaan ihmismieleen ja merkityksenantoon palautuvaa lukemista ja representationalistista tapaa ajatella kirjallisuutta. Esimerkiksi Askinin luenta Ana Castillon The Mixquiahuala Letters -teoksesta (1986) ei väitä, että teos on tietyn kulttuurisen, poliittisen ja taloudellisen tilanteen representaatiota sekä vastarintaista hybridisyyden politiikkaa. Askinille romaani on poliittinen teos, mutta sen poliittisuus saa ilmaisunsa nimenomaisesti kirjallisuutena eikä jonkin teoksen ulkopuolelle viittaavan ilmiön uudelleen-esittämisenä eli re-presentaationa. Askinin mukaan Castillon romaani ei siis uusinna olemassa olevia poliittisia näkemyksiä maailmantilanteesta, vaan hänen luennassaan painopiste on siinä, miten romaani rakentaa ilmaisullaan, teemojen ja rakenteen kautta poliittisia kytkentöjä. Ero representationalistiseen ajatteluun syntyy siitä, että Askinille kirjallisuus luo politiikkaa eikä toista tai uudelleen esitä sitä.

Askin tarkastelee myös Michael Ondjaatjen The Collected Works of Billy the Kid -teosta (1970), Colson Whiteheadin The Intuitionistia (1999) sekä Mark Z. Danielewskin House of Leaves -romaania (2000). Vaikka Askin toteaa kaikkien tarkastelemiensa teosten olevan enemmän tai vähemmän kokeellisia, hänen mukaansa differentiaalinen narratologia sopii kaikenlaisen kirjallisuuden tarkasteluun. Askinin tapa lukea teoksia on tarkkaa, ja se kiinnittyy yhtä paljon narratiivien muotoon kuin temaattisiin kysymyksiin.

Kokonaisuudessaan Narrative and Becoming saa kuitenkin miettimään, miksi Askin kutsuu ajattelutapaansa narratologiaksi, kun tutkimus kuitenkin irtisanoutuu niin monista narratologisiksi nimetyistä ajattelutavoista. Nähtävästi Askinin yhtenä tavoitteena on saada keskustelua aikaiseksi nimenomaisesti narratologisissa piireissä. Deleuzen ja Guattarin ajattelua tunteville tutkimus on kiinnostava havainnollistaessaan filosofien käsitteiden käyttöä aineistona olevien teosten analyyseissä. Jos Deleuzen käsitteistö ja ajattelutapa eivät ole ennalta tuttua, vaatii Askinin teos hidasta lukemista: kaikessa aktuaalisuudessaankin tutkimus on kovin abstrakti, ja siinä mielessä se onnistuu kyllä hyvin tavoitteessaan.

\section{Kaisa Kurikka}

